\title{
Abrasive wear effect on Polyethylene, Polyamide 6 and polymeric particle composites
}

Müller Miroslav, Asc. Prof. Ing., Ph.D., Valášek Petr Ing., Ph.D., Department of Material Science and Manufacturing Technology, Faculty of Engineering, Czech University of Life Science.

E-mail: muller@tf.czu.cz.

An agricultural machine construction is exposed to significant effects of functional areas wearing. The application of polymeric materials and composite materials seems to be prospective. The abrasive wear resistance was tested on rotating cylindrical drum device with the abrasive cloth of the grain size P120. Various modifications of polymeric particle composites, Polyethylene and Polyamide 6 were tested. The polymeric particle composites research and production were focused on knowing the dependence among a two-component epoxy adhesive and various concentration and fraction of corundum hardening particles $\mathrm{Al}_{2} \mathrm{O}_{3}$. Polymeric particle composites showed a potential possibility to resist to high abrasive wear (evaluated decreases in volume) when applying the hardening phase of the grain sizes F80 and F240 and the concentration no exceeding $45 \%$. They showed a low density $\rho 1.20$ till $2.00 \mathrm{~g} \cdot \mathrm{cm}^{-3}$ comparing the steel $\left(\rho=7.75 \mathrm{~g} \cdot \mathrm{cm}^{-3}\right)$.

Keywords: polymers, polymer particle composite, resistance, two-body abrasion with impact, wear

\section{Acknowledgement}

\section{Supported by Internal grant agency of Faculty of Engineering, Czech University of Life Sciences in Prague}

\section{References}

[1] RAVI KUMAR, B.N.; SURESHA, B.; VENKATARAMAREDDY, M. Effect of particulate fillers on mechanical and abrasive wear behaviour of polyamide 66/polypropylene nanocomposites. Materials and Design, 2009, vol. 30 , p. 3852-3858.

[2] SURESHA, B.; RAVI KUMAR, B. N. Two-body Abrasive Wear Behavior of Particulate Filled Polyamide66/Polypropylene Nanocomposites. Journal of Applied Polymer Science, 2010, vol. 119, p. 2292-2301.

[3] ER U.; PAR B. Wear of plowshare components in SAE 950C steel surface hardened by powder boriding. Wear, 2006, vol. 261, p. 251-255.

[4] HORVAT Z.; FILIPOVI D.; KOSTIC S. ; EMERT R. Reduction of mouldboard plough share wear by a combination technique of hardfacing. Tribology International, 2008, vol. 41, p. 778-782.

[5] SARE I. R.; CONSTANTINE A. G. Development of methodologies for evaluation of wear-resistant materials for mineral industry. Wear, 1997, vol. 203-204, p. 671-678

[6] HRABĚ, P.; MÜLLER, M.; CHOTĚBORSKÝ, R. Vybrané návarové materiály a jejich laboratorní porovnání proti abrazivnímu opotřebení. Strojírenská technologie, 2007, vol. 12, no. special number, p. 77-80.

[7] PALABILYIK, M.; BAHADUR, S. Tribological studies of polyamide 6 and high-density polyethylene blends filled with PTFE and copper oxide and reinforced with short glass fibers. Wear, 2002, vol. 253, p. 369-376.

[8] PALABILYIK, M.; BAHADUR, S. Mechanical and tribological properties of polyamide 6 and high density polyethylene polyblends with and without compatibilizer. Wear, 2000, vol. 246, p. 149-158.

[9] MÜLLER, M. Polymeric composites based on $\mathrm{Al}_{2} \mathrm{O}_{3}$ reinforcing particles. In $10^{\text {th }}$ International scientific conference engineering for rural development. 26-27 May, 2011. Edit. by Latvia University of Agriculture. Jelgava, c2011, p. 423-427.

[10] MÜLLER, M.; VALÁŠEK, P. Polymerní kompozity na bázi zpevňujících částic odpadů z procesu mechanické povrchové úpravy. Strojírenská technologie, 2010, vol. 14, no. special number, p. 183-186.

[11] VALAŠEK, P.; MÜLLER, M. Vliv plniva na bázi odpadního abraziva z otryskávání na pevnostní charakteristiky polymerních částicových kompozitů. Strojírenská technologie, 2011, vol. 16, no.1, p. 36-39.

[12] MÜLLER M.; VALÁŠEK P.; NOVÁK P.; HRABĚ P.; PAŠKO J. Aplikace návarů a kompozitů v oblasti technologie pěstování a sklizně cukrové řepy. Listy cukrovarnické a řepařské. 2011, vol. 127, p. 304-307.

[13] BROŽEK, M. Abrasive wear resistance of selected hardfacing materials. Manufacturing Technology, 2005 , vol. 5, no. 1, p. 5-9.

[14] MAŇAS, D.; STANEK, M.; MAŇAS, M.; LUKOVICS, I. Wear of Rubber Parts. Manufacturing Technology, 2006, vol. 6, no. 1, p. 26-30. 
[15] ČSN 62 1466: 1993. Rubber, determination of abrasion resistance using a rotating cylindrical drum device. Prague: Federal office for standard and measuring, $1993.12 \mathrm{p}$.

[16] ČSN EN ISO 868: 2003. Plastics and ebonite - Determination of indentation hardness by means of durometr (Shore hardness). Czech Standard Institution, Prague, 2003. 10 p.

[17] BERTHELOT, J. M. Composite Materials - Mechanical Behavior and Structural Analysis. Mechanical engineering series. Berlin, 1998, 635 p.

[18] JANČÁ̌̌, J. Úvod do materiálového inženýrství polymerních kompozitů. Brno: VUT, 2003, 194 p.

Paper number: M201213

Manuscript of the paper recieved in 2012-03-19. The reviewers of this paper: Assoc. Prof. Jitka Podjuklova, MSc, Ph.D. and Assoc Prof. Pavel Novak, MSc., Ph.D. 